\title{
The effects of intrauterine undernutrition on pancreas ghrelin and insulin expression in neonate rats
}

\author{
Xiumin Wang, Li Liang and Lizhong Du \\ Department of Endocrinology, The Children's Hospital of Zhejiang University School of Medicine, 57 Zhugan Xiang, Hangzhou 310003, China \\ (Requests for offprints should be addressed to L Du; Email: dulizhong@yahoo.com.cn)
}

\begin{abstract}
Ghrelin has a correlation with insulin secretion, $\beta$-cell development, and diabetes in crucial development period. The aim of this study was to compare the changes in plasma ghrelin, insulin, and glucose concentrations, and variation of ghrelin expression in the pancreas in response to intrauterine malnutrition in newborn rats. Pregnant rats at day 2 were randomly divided into two groups: nourished (fed ad libitum; NR) and undernourished rats (UR). The offspring of NR were defined as normal-birth-weight group (NBW, $n=79)$ and those of UR were defined as low-birth-weight group (LBW, $n=74$ ). Plasma glucose, ghrelin, and serum insulin of both dams and their pups were analyzed at the first day after birth. The entire pancreas was collected for determination of ghrelin and insulin mRNAs, and quantification of pancreas ghrelin and insulin. Immunohistochemical double staining and confocal microscopy were performed on rat pancreas. Birth weight was $5 \cdot 81 \pm 0.64$ and $4 \cdot 76 \pm 0 \cdot 23 \mathrm{~g}$ in NBW group and LBW group respectively. Fasting plasma ghrelin concentrations in UR group (1382 (1287-1513) pg/ml) were higher than that of NR
\end{abstract}

group (1072 (974-1205) pg/ml). Plasma ghrelin concentrations in the LBW group (2176 (2031-2384) pg/ml) were significantly lower than that of the NBW group (2493 (2311-2675) pg/ml). Undernutrition caused a decrease in plasma insulin concentrations in both UR dams and LBW pups $(P<0 \cdot 001)$. Ghrelin mRNA and total ghrelin of pancreas were significantly affected by intrauterine nutrition state. Pancreas insulin concentrations were significantly affected by intrauterine nutrition $(P=0 \cdot 007)$. The majority of ghrelin-producing cells were present at the periphery of islets in the NBW group. Ghrelin was colocalized with insulin in $\beta$-cells in LBW group. The percentage of ghrelin-positive cells in the islets of LBW group was significantly higher than that of the NBW group $(P<0 \cdot 01)$. Intrauterine undernutrition may affect the birth weight, plasma insulin and ghrelin levels, islet ghrelin expression, and ghrelin cell distribution. It will be interesting to investigate intrauterine nutrition which is involved in islet ghrelin expression and ghrelin cell distribution.

Journal of Endocrinology (2007) 194, 121-129

\section{Introduction}

Ghrelin is a 28 -amino acid peptide secreted mainly by the gastrointestinal tract (stomach, duodenum, and jejunum). It is also present in the placenta, the hypothalamus, and the pancreas. Ghrelin may play a role in meal initiation in humans and rodents (Kojima et al. 1999, Shuto et al. 2001). Ghrelin secretion was nutritionally manipulated. The relationship between ghrelin, insulin, and glucose remains unclear. There is a reciprocal change in plasma ghrelin and insulin concentrations after a meal. Most human and animal studies have shown that hyperglycemia and insulin (without hypoglycemia) decrease plasma ghrelin. In human neonates, a large amount of ghrelin is present in umbilical cord plasma samples (Farquhar et al. 2003).

In the adult rat, ghrelin appears to affect insulin secretion by the pancreas. Both stimulatory and inhibitory effects of ghrelin on insulin secretion have been reported. The role of ghrelin in the fetus remains unclear. In Nkx2.2 or Pax4 gene knockout mouse models, $\mathrm{Nkx} 2.2$ and $\mathrm{Pax} 4$ are required to specify or maintain differentiation of the cell fate; ghrelin cells replace insulin-producing $\beta$-cells in pancreas development. The expansion of ghrelin-producing cells is at the expense of cells (Prado et al. 2004). Interestingly, in humans, ghrelin is abundant in the fetal pancreas (but not the adult pancreas), where ghrelin-secreting cells represent up to $10 \%$ of the endocrine cells. Ghrelin is expressed in a novel endocrine cell type in developing rat islets and inhibits insulin secretion from INS-1 (832/13) cells (Wierup et al. 2004). Ghrelinimmunoreactivity cells were observed in $2 \cdot 6$ and $3 \cdot 8 \%$ of the total cell population in the islet of Langerhans of normal and diabetic rats respectively (Adeghate \& Ponery 2002a,b, Wierup et al. 2002). Ghrelin inhibits insulin and stimulates glucagon secretion from the pancreatic islets of the mouse and rat and is related to diabetes (Adeghate \& Ponery 2002a,b, Katsuki et al. 2004).

The prevalence of type 2 diabetes is much higher in adults with a low weight at birth; intrauterine malnutrition is associated with impaired insulin secretion and increased susceptibility to diabetes (Barker 1993, Hofman et al. 2004). 
The mechanism between intrauterine malnutrition and increased susceptibility to diabetes is unclear. The reduced insulin secretion in islets of low-protein pups may result from intrinsic alterations in the islets, such as a smaller size and/or a reduced volume of B-cells (Dahri et al. 1991). Maternal food restriction can result in the early developmental $\beta$-cell alteration, and this alteration further generates inadequacies in adult endocrine pancreas to adapt to situations of increased insulin demand (Garofano et al. 1998).

Because ghrelin has a correlation with insulin secretion, B-cell development, and diabetes in crucial development period, we speculated that pancreas ghrelin expression may be a key bridge to the association between low birth weight and increased susceptibility to diabetes. We hypothesized that intrauterine malnutrition may alter fetal circulating and tissue ghrelin, and that ghrelin distribution in pancreas may differ in normal-birth-weight (NBW) and low-birth-weight (LBW) rats. Meanwhile, we compared the changes in plasma ghrelin, insulin, and glucose concentrations, and in ghrelin gene expression in pancreas in response to intrauterine malnutrition in newborn rats.

\section{Material and Methods}

\section{Animal model}

All procedures used in this study were approved and performed in accordance with the guidelines established by the Animal Ethics Committee of the Zhejiang University School of Medicine. Twenty Sprague-Dawley (SD) pregnant rats (12 weeks old, 250-300 g, day 2 of pregnancy at the time of the experiment) obtained from Zhejiang Medical Science Academy (Hangzhou, China) were used to generate the offspring used in this study. The rats were housed in a $22 \pm$ $1{ }^{\circ} \mathrm{C}$ environment at $60 \%$ humidity and were maintained on a $12 \mathrm{~h}$ light:12 h darkness cycle.

\section{Feeding protocol}

The rats were housed individually in standard rat cages at day 2 of the pregnancy. Pregnant rats were randomly divided into two groups: nourished (fed ad libitum; NR) and undernourished rats (UR). Rats in the NR group were fed a standard commercial rat diet, which contained (per $100 \mathrm{~g}$ ) protein $(22.5 \mathrm{~g})$, carbohydrates $(57 \cdot 0 \mathrm{~g})$, fat $(3.9 \mathrm{~g})$, cellulose $(8 \cdot 0 \mathrm{~g})$, minerals $(1 \mathrm{~g})$, vitamins (mixed, $5.0 \mathrm{~g})$, and water $(2.5 \mathrm{~g})$. Rats in the UR group were fed the same diet at $50 \%$ of the NR intake, as determined by the amount of food consumed by the control group, from day 2 of pregnancy until day 23 (parturition). Water was provided ad libitum. All rats were fed daily, in the morning, and the consumption was determined $24 \mathrm{~h}$ later. The body weight of dams was determined during pregnancy (on days 5, 10, 15, and 20), and the body weight of pups was determined at birth. To prevent variation in neonatal growth related to the unavailability of milk, all the pups were killed within $2 \mathrm{~h}$ after birth without suckling. Therefore, UR pups differed from NR pups only in their prenatal dietary experience. After parturition, all the dams were fasted for $10 \mathrm{~h}$ and killed by anesthesia. Pentobarbital sodium (60 mg/kg, i.p.) was used before killing. The time between anesthesia induction and killing was no more than $10 \mathrm{~min}$.

Effect of maternal undernutrition on plasma ghrelin, insulin, and glucose concentrations, and on pancreatic ghrelin and insulin gene expression

Twenty delivered female rats and their offspring were used. The offspring of NR were defined as NBW group $(n=79)$; the pups of UR were defined as LBW group $(n=74)$. Plasma glucose, ghrelin, and insulin of both dams and their pups were analyzed at the first day after birth. One plasma EDTA aliquot was collected from each dam. Fetal EDTA plasma was pooled from two to three pups ( $n=30$ samples per group of pups). Plasma concentrations of total ghrelin and insulin were determined in all samples (plasma EDTA without additives). One microliter of dam or pup blood was used at the time of the experiment to determine the plasma glucose concentrations. All samples were kept on ice until centrifugation and stored thereafter at $-80^{\circ} \mathrm{C}$ until the assay was performed. The entire pancreas was collected. All tissue samples were immediately frozen at $-80{ }^{\circ} \mathrm{C}$ for later determination of total ghrelin concentrations and ghrelin and insulin mRNAs, as appropriate.

\section{Hormone determinations}

Ghrelin circulates in two forms: a biologically active (octanoylated) and inactive (des-octanoylated) form. In these experiments, plasma total (active and inactive) ghrelin (RK-031-30, Phoenix, Belmont, CA, USA) and insulin (Boster, Wuhan, China) immunoreactivities were determined by RIA. All determinations in one experiment were performed in duplicate in the same assay. Glucose was determined by the glucose oxidase method using Hitachi System 717 (Roche Diagnostics, Basel, Switzerland).

\section{Ghrelin and insulin RT-PCR}

Ghrelin and insulin mRNAs were estimated by RT-PCR with slight modifications and the results normalized for B-actin. Total RNA was extracted using TRIzol reagent (Life Technologies) according to manufacturer's protocol. Two micrograms of total RNA were used for RT. cDNAs were synthesized using $200 \mathrm{U}$ Moloney murine leukemia reverse transcriptase (Life Technologies), $6 \mu \mathrm{l}$ dNTPs mix (10 mM of each dNTP), $6 \mu \mathrm{l}$ firststrand buffer (250 mM Tris- $\mathrm{HCl}(\mathrm{pH} 8 \cdot 3), 375 \mathrm{mM} \mathrm{KCl}$, $15 \mathrm{mM} \mathrm{MgCl}_{2}$ (Life Technologies)), 2.75 $\mu$ l random hexamer solution (200 ng/ $\mu \mathrm{l}$; Invitrogen Life Technologies), and 0.25 $\mu \mathrm{l}$ RNase Out (recombinant ribonuclease inhibitor, $40 \mathrm{U} / \mu \mathrm{l}$; Invitrogen) in a total volume of $30 \mu \mathrm{l}$. Reaction mixtures were incubated at $37^{\circ} \mathrm{C}$ for $60 \mathrm{~min}$ and $42{ }^{\circ} \mathrm{C}$ for $10 \mathrm{~min}$. 
The reaction was stopped by heating at $95^{\circ} \mathrm{C}$ for $5 \mathrm{~min}$ and subsequently quickly chilled on ice. Three microliters of RT reaction were used for PCR amplification. The amplification conditions were as follows: $5 \mu \mathrm{PCR}$ buffer $(200 \mathrm{mM}$ Tris- $\mathrm{HCl}$ ( $\mathrm{pH} \mathrm{8.4)} \mathrm{and} 500 \mathrm{mM} \mathrm{KCl}$ (Life Technologies)), 1.5 $\mu \mathrm{l}$ of $50 \mathrm{mM} \mathrm{MgCl}_{2}, 4 \mu \mathrm{dNTPs} \operatorname{mix}(10 \mathrm{mM}$ of each dNTP), $2 \mu \mathrm{l}$ of $10 \mu \mathrm{M}$ solutions of upstream and downstream primers, and 2.0 U Taq DNA polymerase (Life Technologies) in a $50 \mu \mathrm{l}$ reaction volume. We used the following primers: rat ghrelin, upstream primer $5^{\prime}$-TTGAGCCCAGAGCACCAGAAA-3' and downstream primer 5'-AGTTGCAGAGGAGGCAGAAGCT-3' (length of the amplicon: $347 \mathrm{bp}$, accession no. AB029433, GenBank; Date et al. 2000); insulin, upstream primer $5^{\prime}$-GGGAACGTGGTTTCTTCTACACA-3' and downstream primer $5^{\prime}$-TCCAGTGCCAAGGTCTGAAGAT-3' (length of the amplicon: $118 \mathrm{bp}$, accession no. gi 56487 , GenBank). The amplification profile was denaturation at $94{ }^{\circ} \mathrm{C}$ for $30 \mathrm{~s}$, annealing at $58^{\circ} \mathrm{C}$ (ghrelin) or $62^{\circ} \mathrm{C}$ (insulin) for $30 \mathrm{~s}$, and extension at $72^{\circ} \mathrm{C}$ for $1 \mathrm{~min}$. Amplification was completed with an additional step at $72{ }^{\circ} \mathrm{C}$ for $10 \mathrm{~min}$. The amplification was performed in an automatic thermal cycler. To normalize the results for differences in RNA sampling, the second half of the RT reaction was used to amplify a of the rat B-actin (upstream primer $5^{\prime}$-TCACCCACACTGTGCCCATCTATGA-3' and downstream primer $5^{\prime}$-CATCGGAACCGCTCATTGCCGATAG-3' (length of the amplicon: $280 \mathrm{bp}$, accession no. AC121985, GenBank).

To ensure that PCR was performed in the linear amplification range, samples of each tissue were taken every two to three cycles over a wide range, showing that the reaction was linear between 26 and 32 cycles for ghrelin and insulin. PCRs were run at 29 cycles. The number of cycles for B-actin was 28 when run with ghrelin or insulin. All reactions presented in a given figure were performed in the same assay. The amplified products of ghrelin were a $347 \mathrm{bp}$ product that spans through the first and fourth exons, and the amplified products of insulin were a $118 \mathrm{bp}$ product, which is confirmed by electrophoresis with DNA ladder marker. PCR products were separated on $1.8 \%$ agarose gel, stained with ethidium bromide, examined with u.v. light, and visualized with a Gel Doc 1000 documentation system (Bio-Rad Laboratories Inc). In addition, multiple negative controls were made by omitting the reverse transcriptase from the reactions, suggesting that the PCR product obtained was not amplified genomic DNA. Finally, both PCR products of ghrelin and insulin were sequenced and compared with the expected sequences, which confirmed the specificity of the PCR product.

\section{Quantification of pancreas ghrelin and insulin}

Pancreas ghrelin. Pancreas ghrelin was extracted as described by Toshinai et al. with slight modifications. Aliquots of pancreas were minced and boiled at $98{ }^{\circ} \mathrm{C}$ for $10 \mathrm{~min}$ in $1 \mathrm{ml}$ water to inactivate the intrinsic proteases. After the samples were cooled to $4{ }^{\circ} \mathrm{C}$ for $2-3 \mathrm{~min}$, acetic acid $\left(\mathrm{CH}_{3} \mathrm{COOH}\right)$ and hydrochloric acid $(\mathrm{HCl})$ were added to the respective final concentrations of $1 \mathrm{M}$ and $20 \mathrm{mM}$. The tissues were then homogenized in a polytron for $2 \mathrm{~min}$, after which the homogenate was centrifuged at $13000 \mathrm{~g}$ for $15 \mathrm{~min}$ at $4{ }^{\circ} \mathrm{C}$. The supernatant was collected and lyophilized. The appropriate RIA measured total ghrelin after reconstitution in $10 \mathrm{mM}$ phosphate buffer with $10 \mathrm{mM}$ EDTA, $0 \cdot 1 \%$ gelatin, and $0 \cdot 08 \%$ sodium azide ( $\mathrm{pH} 6 \cdot 85)$.

Insulin secretion. Islets were isolated by collagenase digestion. Briefly, the pancreas was inflated with Hanks solution containing $0 \cdot 7-0.9 \mathrm{~g}$ collagenase $/ 1$, excised, and then maintained at $37^{\circ} \mathrm{C}$ for $20 \mathrm{~min}$. The digested tissue was harvested and the islets were handpicked. Groups of five islets were first incubated for $45 \mathrm{~min}$ at $37^{\circ} \mathrm{C}$ in $0.5 \mathrm{ml} \mathrm{Krebs-bicarbonate}$ buffer of the following composition (mmol/l): $115 \mathrm{NaCl}, 5$ $\mathrm{KCl}, 2.56 \mathrm{CaCl}_{2}, 1 \mathrm{MgCl}_{2}, 24 \mathrm{NaHCO}_{3}$, and 5.6 glucose, supplemented with $3 \mathrm{~g} / \mathrm{BSA}$ and equilibrated with a mixture of $95 \% \mathrm{O}_{2} / 5 \% \mathrm{CO}_{2}(\mathrm{pH} 7 \cdot 4)$. This medium was then replaced with fresh buffer and the islets incubated for $90 \mathrm{~min}$ in the presence of $16.7 \mathrm{mmol} / 1$ glucose. Insulin was measured by RIA in the medium at the end of the incubation period.

\section{Immunofluorescence double staining, DAPI staining, and confocal microscopy}

Ghrelin and insulin or glucagon double fluorescence immunostaining was performed on formalin-fixed and paraffin-embedded rat pancreas, using poly-L-lysin-coated slides. Each slide was about $4 \mathrm{~mm}$, dextraned by dimethylbenzene, and dehydrated by gradient ethanol. A standard manual immunofluorescence procedure was used with antigen retrieval procedure. Antigen retrieval was done by modified high-temperature technique pioneered by Shi et al. (1997). The procedure was as follows: each section was deparaffinized twice, $10 \mathrm{~min}$ each in $100 \%$ xylene, and then hydrated with $100 \%$ ethanol for $5 \mathrm{~min}$, twice, $95 \%$ ethanol for $3 \mathrm{~min}$, and $80 \%$ ethanol for $5 \mathrm{~min}$. After $2-5 \mathrm{~min}$ of soaking in distilled water, the slides were put into the pressure cooker filled with $1000 \mathrm{ml}$ boiling sodium citrate buffer (pH 6.0) and heated under pressure. Two minutes after steaming, the pressure cooker was removed from the heating source and cooled down to room temperature with tap water. The slides were rinsed $2 \times 3 \mathrm{~min}$ with PBS. Afterward, the primary antibody was applied.

First, in order to detect ghrelin-like immunoreactivity, the sections were incubated with a rabbit anti-rat ghrelin (amino acids 13-28; FG-G-031-30 Phoenix), diluted 1:500, and the sections were incubated with the ghrelin antibody for $1 \mathrm{~h}$ at $37^{\circ} \mathrm{C}$, then washed in PBS buffer for $3 \times 5 \mathrm{~min}$. Subsequently, the sections were then incubated with rhodamine B-labeled serum goat anti-rabbit antibody (1:400, ZF-0316 Zymed) for $40 \mathrm{~min}$ at $37^{\circ} \mathrm{C}$, and then washed in PBS buffer for $3 \times 5 \mathrm{~min}$. A subsequent washing step was performed in hot PBS (at $95^{\circ} \mathrm{C}$ ) to reduce the background and increase sensitivity.

Next, in order to demonstrate simultaneously the presence of insulin-like immunoreactivity or glucagon-like immunoreactivity on the same section as that in which ghrelin-like immunoreactivity was detected, a double 
immunofluorescence technique was performed in sequence. Sections were incubated with a monoclonal mouse anti-rat insulin antibody (1:1500, Clone K36aC10, BM0080 Boster) or a monoclonal mouse anti-rat glucagon antibody $(1: 200$, Clone K796B10, No.G2654; Sigma) for $1 \mathrm{~h}$ at $37^{\circ} \mathrm{C}$, followed by incubation with serum goat anti-mouse antibody labeled with fluorescein-5-isothiocyanate (FITC; 1:400, ZF-0312 Zymed) for $40 \mathrm{~min}$ at $37^{\circ} \mathrm{C}$. Control experiments were included in serial sections by omitting either primary antibody. In experimental conditions, no cross-reactivities were observed in the control tissues. The slides were then counterstained with the nuclear stain $4^{\prime}-6$ diamidino-2-phenylindole (DAPI; Sigma) to detect the number of islet cells and mounted with antifade reagent, and thus DAPI staining was preformed. Briefly, after quick wash with PBS, the slides were incubated for $5 \mathrm{~min}$ with DAPI at a concentration of $0 \cdot 025 \mathrm{mg} / \mathrm{ml}$. Excess staining was removed by rinsing in PBS and in distilled water for $3 X$ $5 \mathrm{~min}$. The sections were enveloped with glycerin.

Double immunolabeling was detected by a Zeiss LSM510 confocal laser scanning microscope (Carl Zeiss Jena, Jena, Germany). This procedure relied on rhodamine-labeled secondary anti-rabbit antibody to reveal ghrelin immune complexes and FITC-labeled anti-mouse secondary antibody to reveal insulin- or glucagon-producing cells. The final tricolor images were compiled from overlaid images of the blue (nuclei), green (insulin or glucagon), and red (ghrelin) images. Point counting for double-positive cells was used for a quantitative analysis of the number of islet cells containing insulin or ghrelin at various sections. Five pancreata were subjected to quantitative analysis in each group. The number of islets of each pancreas section varied from 9 to 19 including large and small islets. By dividing the number of ghrelin-positive $\left(\right.$ ghrelin $^{+}$) cells or insulin-positive (insulin ${ }^{+}$) cells by the number of DAPI-positive $\left(\mathrm{DAPI}^{+}\right)$cells in each islet, the percentage of ghrelin ${ }^{+}$or insulin ${ }^{+}$cells was determined, and the results were presented as mean percentage per islet per section (section number, $n=5$ ). In some sections, the percentage of ghrelin ${ }^{+}$insulin $^{+}$cells or ghrelin ${ }^{+}$ glucagon ${ }^{+}$cells was also determined as above.

\section{Statistical analysis}

Data are presented as mean (95\% confidence interval; CI) or median (range) as appropriate. Statistical analysis was performed by independent-samples $t$-test as appropriate. A $P$ value of $<0.05$ was regarded as significant. Means and $95 \%$ CIs were used to perform comparisons and define significance between individual subgroups.

\section{Results}

Effect of maternal undernutrition on plasma ghrelin and insulin concentrations

As mentioned earlier, NR and UN refer to the dams, and LBW and NBW refer to the pups during grouping. Body weight of both dams and fetuses was significantly affected by feeding status $(P<0 \cdot 001)$. After parturition, mean $(95 \% \mathrm{CI})$ body weight was 287 (265-326) g in NR rats and 234 (198267) $\mathrm{g}$ in UR animals. In the NBW group (NR pups), body weight at birth was $5 \cdot 81 \pm 0.64 \mathrm{~g}$, whereas in the LBW group (UR pups), it was $4 \cdot 76 \pm 0 \cdot 23 \mathrm{~g}$. Median (range) number of fetuses per dam was 7 (5-13) and was not affected by maternal feeding state.

Plasma total ghrelin concentrations were significantly affected by feeding state $(P<0 \cdot 001$; Fig. 1A). After parturition, fasting plasma ghrelin concentrations in UR group $(1382(1287-1513) \mathrm{pg} / \mathrm{ml})$ were higher than that of NR group (1072 (974-1205) pg/ml). Ghrelin concentrations were two to three times higher in pups when compared with their mothers. At the first day after birth, pups' plasma ghrelin concentrations in the LBW group (2176 (2031-2384) pg/ml) were significantly lower than that of NBW group (2493 (2311-2675) $\mathrm{pg} / \mathrm{ml})$, which was in contrast to what was observed in the dams. Plasma insulin concentrations were significantly affected by nutrition state $(P<0 \cdot 001)$. Undernutrition caused a decrease in plasma insulin concentrations in both UR dams and LBW pups (Fig. 1B). Plasma glucose concentrations were also significantly affected by maternal nutrition state $(P<0 \cdot 001)$. Fasting caused a significant decrease in plasma glucose concentrations in the dams as well as in their fetuses (Fig. 1C).

Effect of intrauterine undernutrition on pups' pancreas ghrelin and insulin gene expression

To determine whether the differences in plasma ghrelin and insulin concentrations observed in the LBW group when compared with the NBW group could be explained by the differences in tissue gene expression, we determined insulin and ghrelin mRNAs and protein in the pancreas of rat pups. Ghrelin mRNA and concentrations of total ghrelin in the pancreas were significantly affected by intrauterine nutrition state. Pancreas ghrelin/B-actin ratio (expressed as percentage) was $372 \%(307-513 \%)$ in the LBW group, which was significantly higher when compared with that in the NBW group (124\% (57-198\%); Fig. 2A). Accordingly, pancreas total ghrelin content was $714(632-759) \mathrm{ng} / \mathrm{g}$ tissue in the LBW group, while it was 479 (381-732) $\mathrm{ng} / \mathrm{g}$ tissue in the NBW group, hence there was a difference in the pancreas total ghrelin content between the two groups $(P<0 \cdot 01$; Fig. 2C). Thus, ghrelin content of pancreas in the pups is influenced by the intrauterine nutrition. To test whether intrauterine nutrition plays a role in pancreas insulin expression, we investigated pancreas insulin mRNA expression and insulin content expressed in the pups. Pancreas insulin/ $\beta$-actin ratio (expressed as percentage) was 112\% (67$194 \%)$ in the LBW group, while it was 183\% (157-302\%) in the NBW group (Fig. 2B). Insulin expression in pup pancreas was affected by maternal nutrition. The results show that insulin content was 782.1 (522-986) pmol/islet-90 min and 2448.9 (1987-2954) pmol/islet-90 min in LBW and NBW 

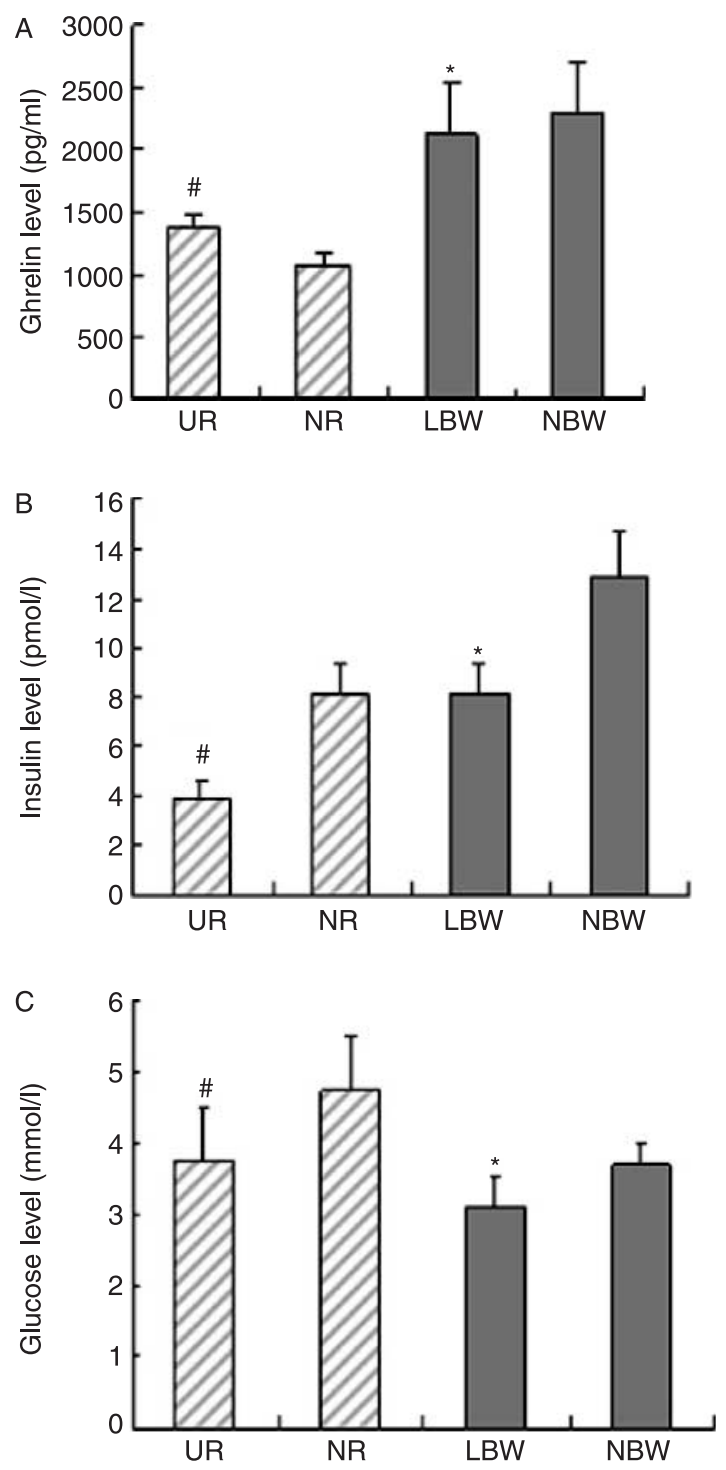

Figure 1 Plasma ghrelin (A), insulin (B), and glucose (C) concentrations in dam rats (UR and NR; $n=10$ per group) and their fetuses (LBW and NBW, $n=30$ per group; mean). Plasma ghrelin, insulin, and glucose concentrations were significantly affected by feeding state $(P<0 \cdot 001)$. ( ${ }^{\#}$ Represents $P<0 \cdot 01$ versus NR group. *Represents $P<0 \cdot 01$ versus NBW group.

groups respectively (Fig. 2D). Pancreas insulin concentrations of newborn rats were significantly affected by intrauterine nutrition $(P=0 \cdot 007)$.

\section{Ghrelin expression in pancreatic islets}

We further investigate the cell type(s) expressing ghrelin in the pancreatic islet by means of double immunofluorescence stains and counterstained with DAPI (Fig. 3).

Pancreatic islet of NBW group showed a strong immunoreactivity for insulin in many B-cells at the center of islets
(Fig. 3A, green), and most of the ghrelin-immunoreactive cells distributed at the periphery of the islets (Fig. 3B, red), which was confirmed by overlapping the two fluorescence reactions (Fig. 3C). A double immunofluorescence for insulin and ghrelin in pancreatic islet of LBW group showed that most of insulin (Fig. 3D, green) and ghrelin (Fig. 3E, red) were colocalized in the center of islet, and majority of insulinproducing cells (or $\beta$-cells) coexpressed ghrelin, as also confirmed by the yellow color obtained by overlapping the two fluorescence reactions (Fig. 3F, yellow). Ghrelin had a preferential central distribution within the endocrine islet of the LBW group. The percentage of ghrelin ${ }^{+}{ }_{\text {insulin }}{ }^{+}$cells in the LBW group was $33 \cdot 7 \%$ (95\% CI: $16 \cdot 2-41 \cdot 1 \%))$. Glucagon $^{+}$cells (Fig. 3G, green), ghrelin ${ }^{+}$cells (Fig. 3H, red), or cells coexpressing both hormones (glucagon ${ }^{+}$ ghrelin $^{+}$cells; Fig. 3I, yellow) in the pancreatic islet of the NBW group were detected. Glucagon ${ }^{+}$cells distributed at the periphery of the islets of the NBW group, and many glucagon ${ }^{+}$cells coexpressed ghrelin. The percentage of ghrelin $^{+}$glucagon $^{+}$cells was 5.3\% (95\% CI: 3.9-9.7\%) in the NBW group. Two populations of cells in the islet of the LBW group were detectable: cells uniquely expressing glucagon (Fig. 3J, green) at the periphery of the islets or cells uniquely expressing ghrelin at the center of the islets (Fig. 3K, red). No glucagon ${ }^{+}$ghrelin $^{+}$cells were found (Fig. 3L). Relative proportions of insulin- and ghrelin-producing cells were compared between the LBW and NBW groups. Further quantitative analysis showed that the percentage of ghrelin ${ }^{+}$ cells and insulin ${ }^{+}$cells was $83 \cdot 1 \%(95 \% \mathrm{CI}: 76 \cdot 2-90 \cdot 1 \%)$ in the

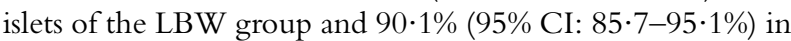
the NBW group respectively (Fig. 3M). The percentage of ghrelin ${ }^{+}$cells in the islets of the LBW group (48.7\% (95\% CI: $33 \cdot 2-56 \cdot 7 \%)$ ) was significantly higher than that of the NBW group (15·3\% (95\% CI: $7 \cdot 2-20 \cdot 1 \%)$; Fig. 3N, $P<0 \cdot 01)$.

\section{Discussion}

Barker (1993) suggested that low birth weight was associated with increased risk of metabolic syndrome in adulthood. The restriction of dietary protein or a global restriction in nutrients during pregnancy gives rise to the offspring with glucose intolerance and insulin resistance (Langley et al. 1994, Vuguin et al. 2004), which supports the above concept. Insulin resistance is recognized as a common underlying feature of metabolic syndrome, but the mechanisms at the cellular and biochemical levels are not completely understood. Some studies have demonstrated a link between poor nutrition in early life and insulin resistance and diabetes in later life. However, the mechanism is unclear. On the basis of the relationship between ghrelin and insulin, we hypothesized that the interactions between ghrelin and insulin in early life might be a possible link between poor nutrition and insulin resistance.

When maternal diet is restricted, the availability of nutrients for transplacental transport is decreased, reducing 

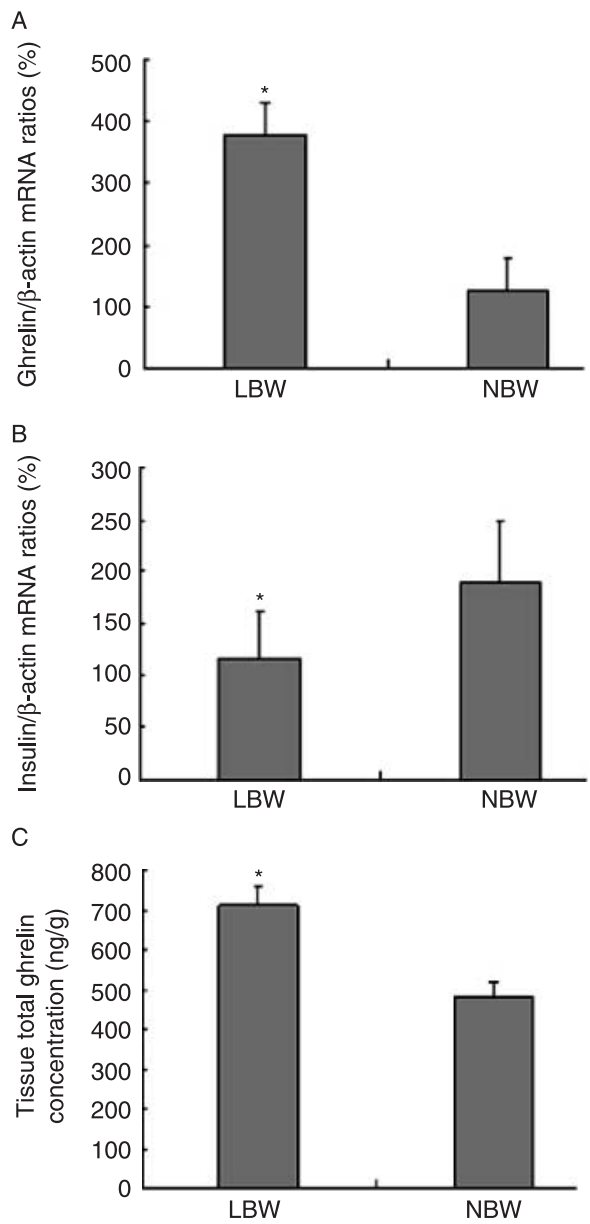

D

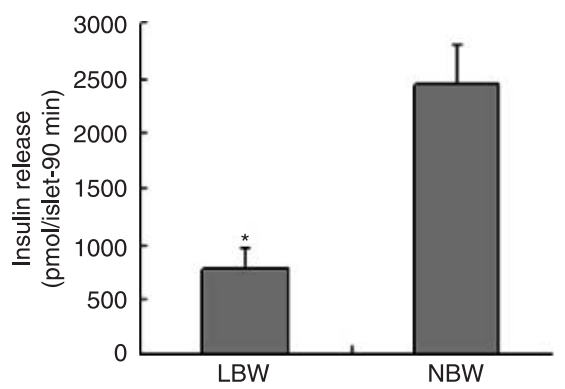

Figure 2 RT-PCR analysis of ghrelin and insulin expression in the pancreas of rat pups. Ghrelin/ß-actin mRNA ratios are expressed as percentage in (A). Insulin/ß-actin mRNA ratios are shown in (B). Ghrelin mRNA and total ghrelin concentrations were significantly affected by intrauterine nutrition state $(P<0 \cdot 001)$. Insulin mRNA expression was significantly affected by intrauterine nutrition state $(P=0 \cdot 009)$ too. Tissue total ghrelin content was determined in pancreas by RIA after extraction and was expressed in nanograms per gram of tissue (figure $C, P<0 \cdot 01$ ). Glucose stimulation

$(16.7 \mathrm{mmol}$ glucose/l) of insulin secretion in islets of pup rats were shown in (figure D); the columns represent the cumulative 90-min insulin secretion and are the means; $n=10$ independent experiments $(P<0 \cdot 01)$. *Represents $P<0 \cdot 01$ versus NBW group. the nutrient supply and thereby limiting the growth of the fetus (Holemans et al. 2003). In the present study, we demonstrated that restriction of maternal nutrition in pregnant SD rats resulted in severe maternal weight loss and in a significant reduction in the birth weight of the offspring. Plasma insulin concentrations in pups were in accordance with their dams; undernutrition caused a decrease in plasma insulin concentrations in both UR dams and LBW pups. Alteration in the maternal metabolic milieu during pregnancy influences the development and functional maturation of $\beta$ cells in fetal pancreas (Sparre et al. 2003). The reduced insulin secretion in islets of LBW pups may result from intrinsic alterations in islets such as a smaller size, a reduced number of $\beta$ - cells, a diminution in the proliferation of islet cells, and a marked decrease in islet vascularization (Snoeck et al. 1990, Boujendar et al. 2003).

Ghrelin and insulin content of pancreas in the pups is influenced by the intrauterine nutrition, which was supported by insulin and ghrelin mRNAs and protein in the pancreas of rat pups. Fasting plasma ghrelin concentrations in UR group were higher than that of NR group, which further supported that ghrelin expression is upregulated under conditions of negative energy balance (Toshinai et al. 2001). Plasma total ghrelin concentrations were markedly higher in pups when compared with their dams, suggesting that the pup plasma ghrelin may originate from different source(s) when compared with their mothers.

Circulating ghrelin of fetuses could originate from the placenta (Gualillo et al. 2001), the stomach (Date et al. 2000, Kojima et al. 1999), or other tissues, such as the pancreas or the lung (Volante et al. 2002a,b) that are known to synthesize ghrelin during early fetal life. Ghrelin is also produced in the hypothalamus (Mozid et al. 2003). In rodents, ghrelin mRNA is present in the stomach by embryonic day 17 of gestation and increases markedly during the first postnatal weeks (Chanoine et al. 2006). The increase in plasma ghrelin concentrations in response to fasting is observed in rats by the end of the first postnatal week (Hayashida et al. 2002, Chanoine \& Wong 2004). The pups in this study were killed within $2 \mathrm{~h}$ after birth without suckling, so the ghrelin concentration in our newborn rats may reflect the ghrelin levels as fetuses. In this study, plasma ghrelin concentrations in the LBW pups were significantly lower than that of the NBW group. However, ghrelin contents in the pancreas of the LBW group were significantly higher than that of NBW group. It seems that there was a discrepancy among these results, that resulted in the lower plasma ghrelin concentrations in the LBW pups. First, placenta ghrelin does not contribute to circulating levels (Fuglsang et al. 2006). Though cord ghrelin concentration was $40 \%$ higher in small for gestational age neonates (SGAs) when compared with appropriate (AGAs) and large (LGAs) for gestational age neonates (Farquhar et al. 2003), circulating fetal ghrelin appears to be derived from a fetal source (Kitamura et al. 2003, Fuglsang et al. 2006). Secondly, ghrelin contents (ng/g) in the pancreas of our LBW group were higher. Maternal food restriction induced a 

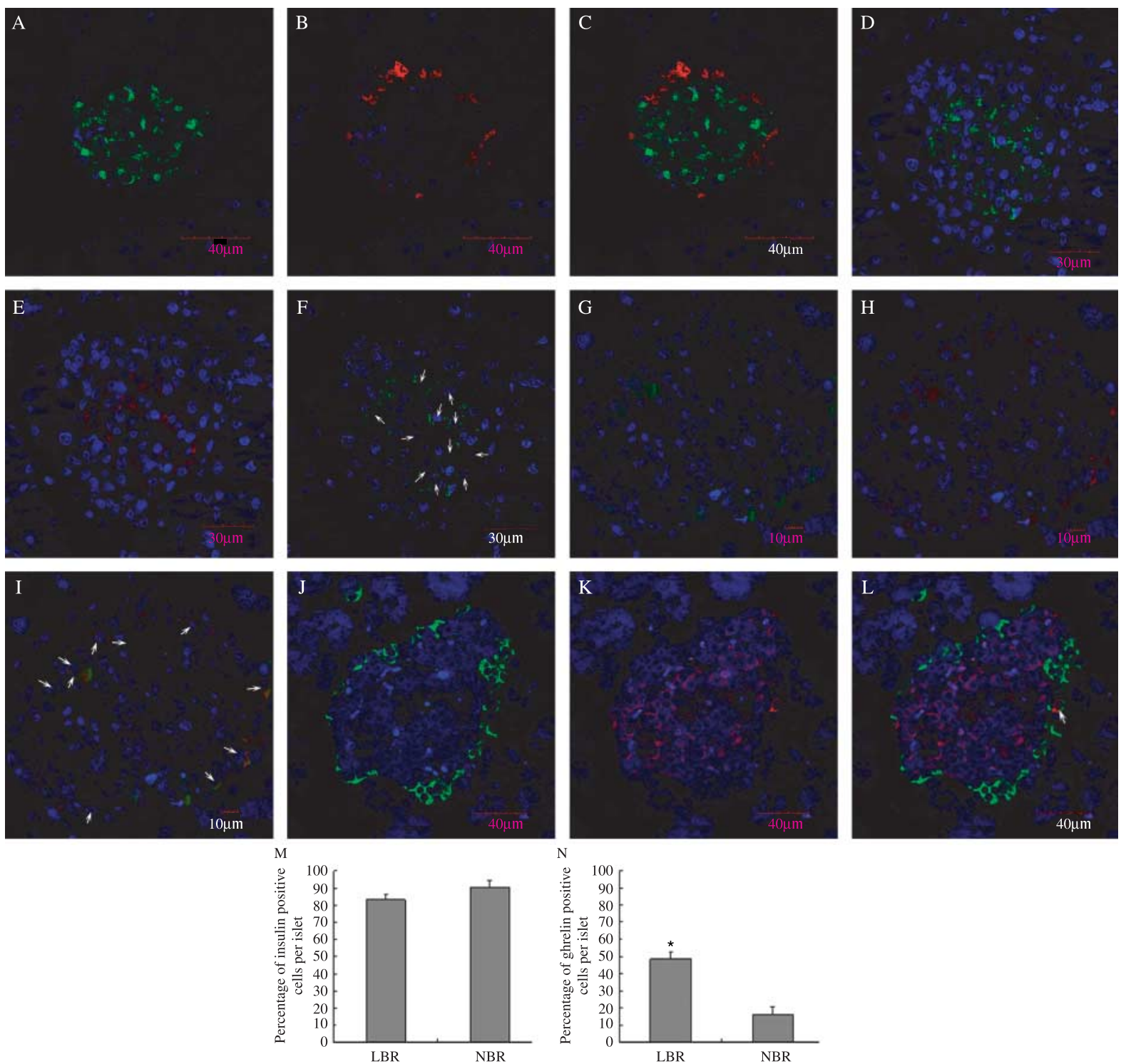

Figure 3 A double immunofluorescence for ghrelin (red) and insulin (green) or glucagon (green) and counterstained with DAPI in pancreatic islet, which was detected by laser confocal fluorescence microscopy. NBW group (ghrelin and insulin double staining: A, B, and C; ghrelin and glucagon: G, H, and I); LBW group (ghrelin and insulin double staining: D, E, and F; ghrelin and glucagon: J, K, and L). Pancreatic islet of the NBW group showed a strong immunoreactivity for insulin in many ß-cells (A, green), most of the ghrelin-immunoreactive cells distributed at the periphery of the pancreatic islets $(B$, red), which was confirmed by overlapping the two fluorescence reactions $(C)$. Glucagon-positive cells $(\mathrm{G}$, green), ghrelin-positive cells $(\mathrm{H}$, red), and cells coexpressing both hormones (l, yellow) in the pancreatic islet of the NBW group were detected. Glucagon cells distributed at the periphery of the islets of the NBW group and many glucagon-positive cells coexpressed ghrelin. Some of the central cells of islets from the NBW group also showed a weak immunoreactivity for ghrelin. A double immunofluorescence for insulin and ghrelin in pancreatic islets of the LBW group showed that most of insulin ( $D$, green) and ghrelin (E, red) were colocalized in the center of islet, and some ß-cells coexpressed ghrelin and insulin, as also confirmed by the yellow color obtained by overlapping the two fluorescence reactions ( $F$, yellow). Two populations of cells in the islets of the LBW group were detectable: cells uniquely expressing glucagon (J, green) at the periphery of the islets or cells uniquely expressing ghrelin at the center of the islets ( $\mathrm{K}$, red), and no cells producing both hormones (L). Relative proportions of insulin- and ghrelin-producing cells were compared between the LBW and NBW groups (M and N). Numbers were provided as the percentage of insulin- and ghrelin-producing cells in relation to the total population of DAPI-immunoreactive cells per islet. The percentage of ghrelin-positive cells in the islets of the LBW group was significantly higher than that of the NBW group $(P<$ $0 \cdot 01)(\mathrm{N})$. Arrows represent ghrelin ${ }^{+}$insulin $^{+}$or ghrelin $^{+}$glucagon ${ }^{+}$double-stained cells. *Represents $P<0 \cdot 01$ versus the NBW group. 
reduction in pancreas weight in the offspring at day 1 after birth (Garofano et al. 1997), which may reduce pancreas whole ghrelin (ghrelin contents $(\mathrm{ng} / \mathrm{g}) \times$ pancreas weight) of LBW pups. Finally, maternal undernutrition not only affected the overall growth of the offspring, but also caused a change in body composition and function, such that the organs were selectively affected. Weight of organs such as liver, muscle, spleen, etc., tended to be proportionally lower than the body weight (Desai et al. 1996). The origin of the high concentration of ghrelin in neonates may need further investigation (Fuglsang et al. 2006); these affected organs should be taken into account. Poor maternal nutrition may result in the decrease of ghrelin cells in these tissues. The decreased ghrelin cells could lead to the decline of ghrelin secretion, which may contribute to the lower plasma ghrelin levels in the LBW group. Further study should be carried out on ghrelin assay to investigate ghrelin expression in these organs and clarify the mechanism.

Ghrelin has powerful effects on islet cells, suggesting that endogenous ghrelin may contribute to the physiological control of insulin and glucagon release (Prado et al. 2004). In the pancreatic endocrine islets, numerous cells expressed ghrelin in the cytoplasm, as indicated by a moderate to intense staining; however, which kind of pancreatic islet cells express ghrelin is still in dispute. In adult rat islets, most of the ghrelinimmunoreactive cells were found at the periphery of the pancreatic islets as $\alpha$-cells, ghrelin-immunoreactive cells colocalized with glucagon in immunofluorescence double staining (Heller et al. 2005). Recently, the expression of the peptide hormone ghrelin was also detected in $\varepsilon$-cells of the islets, a newly discovered endocrine cell type (Wierup et al. 2002 , 2004). In the present study, we provide further evidence that ghrelin coexpressed in the $\alpha$-cells of NBW rat islets, which was in accordance with the previous result (Heller et al. 2005); but in the LBW group, most of the ghrelin-immunoreactive cells distributed in the center of islet cells, and some B-cells coexpressed ghrelin and insulin, and the percentage of ghrelin-positive cells in the LBW group was significantly higher than that of the NBW group. It indicated that intrauterine undernutrition might affect ghrelin expression abundance and the distribution of ghrelinproducing cells in newborn rat pancreatic islets. Prado et al. (2004) found that insulin and ghrelin cells share a common progenitor, and that $\mathrm{Nkx} 2.2$ and $\mathrm{Pax} 4$ are required to specify or maintain differentiation of the $\beta$-cell fate. We speculated that intrauterine nutrition may be a regulating component in $\beta$-cell differentiation in prenatal life, which is the key period of $\beta$-cell development; intrauterine undernutrition of LBW newborn rats may affect the differentiation of progenitor cell to ghrelin cell. Ghrelin cells are most numerous pre- and neonatally and decrease gradually after birth (Wierup \& Sundler 2005). Ghrelin may play a role in meal initiation in human and rodents. Poor maternal nutrition may also permanently alter glucose/insulin metabolism directly through the availability of nutrients for transfer to the fetus (Oliver et al. 2005). In the condition of intrauterine undernutrition, fetus needs higher ghrelin level to take more nutrients. In order to adapt to the undernutrition state, ghrelin cells secreted more ghrelin, which may lead to the delayed disappearance of ghrelin cells in the pancreas of LBW newborn rats.

Numerous experimental studies have shown that nutritional deficiencies during critical periods of life result in a range of fetal adaptations and developmental changes (Barker 1993). Although these adaptations may be beneficial for short-term survival, they can lead to permanent alterations in body structure and metabolism, and thereby to cardiovascular and metabolic diseases in adult life (Arantes et al. 2002). There is a genetic component underlying the balance between insulin and ghrelin in regulating glucose metabolism. Maternal diet could affect gene expression in offspring (Park et al. 2003). Ghrelin may play a role in the pathological procedure of diabetes. Taken together, though it remains unclear how ghrelin is related in lineage to diabetes, here, we supposed that islet ghrelin cell alterations caused by intrauterine undernutrition may be a key linked to the correlation of low birth weight and adulthood diabetes.

In conclusion, the present study showed that intrauterine undernutrition may affect birth weight, plasma insulin level, ghrelin level, islet ghrelin expression, and ghrelin-positive cell distribution. Thus, it will be interesting to investigate the intrauterine nutrition that is involved in islet ghrelin expression and ghrelin cell distribution. Further studies will be required to elucidate the mechanisms by which malnutrition in early life causes permanent changes in later life.

\section{Acknowledgements}

The authors would like to thank technician Wei-zhong Gu for technical assistance. This work was also supported by the central laboratory of the Children's Hospital of Zhejiang University School of Medicine.

\section{Funding}

This work was supported by the Natural Science Foundation of Zhejiang Province of China (J20060685). The authors hereby declare that there is no conflict of interest that would prejudice the impartiality of this scientific work.

\section{References}

Adeghate E \& Ponery AS 2002a Ghrelin stimulates insulin secretion from the pancreas of normal and diabetic rats. Journal of Neuroendocrinology 14 555-560.

Adeghate E \& Parvez H $2002 b$ Mechanism of ghrelin-evoked glucagon secretion from the pancreas of diabetic rats. Neuro Endocrinology Letters $\mathbf{2 3}$ $432-436$. 
Arantes VC, Teixeira VP, Reis MA, Latorraca MQ, Leite AR, Carneiro EM, Yamada AT \& Boschero AC 2002 Expression of PDX-1 is reduced in pancreatic islets from pups of rat dams fed a low protein diet during gestation and lactation. Journal of Nutrition 132 3030-3035.

Barker DJ 1993 Fetal origins of coronary heart disease. British Heart Journal 69 195-196.

Boujendar S, Arany E, Hill D, Remacle C \& Reusens B 2003 Taurine supplementation of a low protein diet fed to rat dams normalizes the vascularization of the fetal endocrine pancreas. Journal of Nutrition $\mathbf{1 3 3}$ 2820-2825.

Chanoine JP \& Wong AC 2004 Ghrelin gene expression is markedly higher in fetal pancreas compared with fetal stomach: effect of maternal fasting. Endocrinology 145 3813-3820.

Chanoine JP, Wong AC \& Barrios V 2006 Obestatin, acylated and total ghrelin concentrations in the perinatal rat pancreas. Hormone Research 66 81-88.

Dahri S, Snoeck A, Reusens-Billen B, Remacle C \& Hoet JJ 1991 Islet function in offspring of mothers on low-protein diet during gestation. Diabetes 40 115-120.

Date Y, Kojima M, Hosoda H, Sawaguchi A, Mondal MS, Suganuma T, Matsukura S, Kangawa K \& Nakazato M 2000 Ghrelin, a novel growth hormone-releasing acylated peptide, is synthesized in a distinct endocrine cell type in the gastrointestinal tracts of rats and humans. Endocrinology 141 4255-4261.

Desai M, Crowther NJ, Lucas A \& Hales CN 1996 Organ-selective growth in the offspring of protein-restricted mothers. British Journal of Nutrition $\mathbf{7 6}$ 591-603.

Farquhar J, Heiman M, Wong AC, Wach R, Chessex P \& Chanoine JP 2003 Elevated umbilical cord ghrelin concentrations in small for gestational age neonates. Journal of Clinical Endocrinology and Metabolism 88 4324-4327.

Fuglsang J, Sandager P, Moller N, Fisker S, Frystyk J \& Ovesen P 2006 Peripartum maternal and foetal ghrelin, growth hormones, IGFs and insulin interrelations. Clinical Endocrinology 64 502-509.

Garofano A, Czernichow P \& Breant B 1997 In utero undernutrition impairs rat beta-cell development. Diabetologia 40 1231-1234.

Garofano A, Czernichow P \& Breant B 1998 Beta-cell mass and proliferation following late fetal and early postnatal malnutrition in the rat. Diabetologia 41 1114-1120

Gualillo O, Caminos E, Blanco M, Garcia-caballero T, Kojima M, Kangawa K, Dieguez C \& Casanueva FF 2001 Ghrelin, a novel placental-derived hormone. Endocrinology 142 788-794.

Hayashida T, Nakahara K, Mondal MS, Date Y, Nakazato M, Kojima M, Kangawa K \& Murakami N 2002 Ghrelin in neonatal rats: distribution in stomach and its possible role. Journal of Endocrinology 17 239-245.

Heller RS, Jenny M, Collombat P, Mansouri A, Tomasetto C, Madsen OD, Mellitzer G, Gradwohl G \& Serup P 2005 Genetic determinants of pancreatic epsilon-cell development. Developmental Biology 286 217-224.

Hofman PL, Regan F, Jackson WE, Jefferies C, Knight DB, Robinson EM \& Cutfield WS 2004 Premature birth and later insulin resistance. New England Journal of Medicine 351 2179-2186.

Holemans K, Aerts L \& Van Assche FA 2003 Fetal growth restriction and consequences for the offspring in animal models. Journal of the Society for Gynecologic Investigation 10 392-399.

Katsuki A, Urakawa H, Gabazza EC, Murashima S, Nakatani K, Togashi K, Yano Y, Adachi Y \& Sumida Y 2004 Circulating levels of active ghrelin is associated with abdominal adiposity, hyperinsulinemia and insulin resistance in patients with type 2 diabetes mellitus. European Journal of Endocrinology 151 573-577.

Kitamura S, Yokota I, Hosoda H, Kotani Y, Matsuda J, Naito E, Ito M, Kangawa K \& Kuroda Y 2003 Ghrelin concentration in cord and neonatal blood: relation to fetal growth and energy balance. Journal of Clinical Endocrinology and Metabolism 88 5473-5477.

Kojima M, Hosoda H, Date Y, Nakazato M, Matsuo H \& Kangawa K 1999 Ghrelin is a growth-hormone-releasing acylated peptide from stomach. Nature 402 656-660.
Langley SC, Browne RF \& Jackson AA 1994 Altered glucose tolerance in rats exposed to maternal low protein diets in utero. Comparative Biochemistry and Physiology. Physiology 109 223-229.

Mozid AM, Tringali G, Forshing ML, Hendricks MS, Ajodhas, Edwards R, Navarra P, Grossman AB \& Korbonits M 2003 ghrelin in released from rat hypothalamic explants and stimulates corticots opin releasing hormone and arginrim- vasopressin. Hormone and metabolic Research 35 455-459.

Oliver MH, Hawkins P \& Harding JE 2005 Periconceptional undernutrition alters growth trajectory and metabolic and endocrine responses to fasting in late-gestation fetal sheep. Pediatric Research 57 591-598.

Park KS, Kim SK, Kim MS, Cho EY, Lee JH, Lee KU, Pak YK \& Lee HK 2003 Fetal and early postnatal protein malnutrition cause long-term changes in rat liver and muscle mitochondria. Journal of Nutrition 133 30853090.

Prado CL, Pugh-Bernard AE, Elghazi L, Sosa-Pineda B \& Sussel L 2004 Ghrelin cells replace insulin-producing beta cells in two mouse models of pancreas development. PNAS 101 2924-2929.

Shi SR, Cote RJ \& Taylor CR 1997 Antigen retrieval immunohistochemistry: past, present and future. Journal of Histochemistry and Cytochemistry $\mathbf{4 5}$ 327-343.

Shuto Y, Shibasaki T, Wada K, Parhar I, Kamegai J, Sugihara H, Oikawa S \& Wakabayashi I 2001 Generation of polyclonal antiserum against the growth hormone secretagogue receptor (GHS-R): evidence that the GHS-R exists in the hypothalamus, pituitary and stomach of rats. Life Sciences 68 991-996.

Snoeck A, Remacle C, Reusens B \& Hoet JJ 1990 Effect of a low protein diet during pregnancy on the fetal rat endocrine pancreas. Biology of the Neonate 57 107-118.

Sparre T, Reusens B, Cherif H, Larsen MR, Roepstorff P, Fey SJ, Mose Larsen P, Remacle C \& Nerup J 2003 Intrauterine programming of fetal islet gene expression in rats-effects of maternal protein restriction during gestation revealed by proteome analysis. Diabetologia 46 1497-1511.

Toshinai K, Mondal MS, Nakazato M, Date Y, Murakami N, Kojima M, Kangawa K \& Matsukura S 2001 Upregulation of ghrelin expression in the stomach upon fasting, insulin-induced hypoglycemia, and leptin administration. Biochemical and Biophysical Research Communications 281 $1220-1225$.

Volante M, Allia E, Gugliotta P, Funaro A, Broglio F, Deghenghi R, Muccioli G, Ghigo E \& Papotti M 2002a Expression of ghrelin and of the GH secretagogue receptor by pancreatic islet cells and related endocrine tumors. Journal of Clinical Endocrinology and Metabolism 87 1300-1308.

Volante M, Fulcheri E, Allia E, Cerrato M, Pucci A \& Papotti M $2002 b$ Ghrelin expression in fetal, infant, and adult human lung. Journal of Histochemistry and Cytochemistry 50 1013-1021.

Vuguin P, Raab E, Liu B, Barzilai N \& Simmons R 2004 Hepatic insulin resistance precedes the development of diabetes in a model of intrauterine growth retardation. Diabetes 53 2617-2622.

Wierup N \& Sundler F 2005 Ultrastructure of islet ghrelin cells in the human fetus. Cell and Tissue Research 319 423-428.

Wierup N, Svensson H, Mulder H \& Sundler F 2002 The ghrelin cell: a novel developmentally regulated islet cell in the human pancreas. Regulatory Peptides 107 63-669.

Wierup N, Yang S, McEvilly RJ, Mulder H \& Sundler F 2004 Ghrelin is expressed in a novel endocrine cell type in developing rat islets and inhibits insulin secretion from INS-1 (832/13) cells. Journal of Histochemistry and Cytochemistry $\mathbf{5 2}$ 301-310.

\section{Received in final form 21 April 2007}

Accepted 24 April 2007

Made available online as an Accepted Preprint 8 May 2007 